\title{
127. Cambrian and Ordovician Faunas of South Korea and the Bearing of the Tsinling-Keijô Line on Ordovician Palaeogeography.
}

\author{
By Teiichi KoBayashi.
}

(Comm. by H. YABE, M.I.A., Dec. 12, 1930.)

One point most interesting and important of the Koreo-Manchurian Ordovician is the striking contrast between the fauna of South Korea and that of North Korea and South Manchuria. The former bears an intimate relation with the Trilobite facies of the European Ordovician, while the latter shows decidedly an Arcto-American affinity. Lately I have studied a rich collection of the Cambrian and Ordovician fossils from South Korea belonging to the Korean Geological Survey, together with those of Mr. T. Shiraki and my owns; of these materials more than eighty species are distinguished in total and these are available for the stratigraphical correlation and the palaeogeographical study.

The stratigraphical sequence observed in the environs of Mt. Tsuibon, Kogen-do, South Korea, is in descending order as follows:

Overlying formation: Heian-System, Permocarboniferous-Triassic in age, with the Koten bed at the base.

unconformity

Ordovician Formation

Bed. O7. Tsuibon limestone. Greyish white limestone, more than $50 \mathrm{~m}$. thick and containing fossils in its lower part.

Bed. $\mathrm{O}_{6}$. Chikunsan shale. Dark grey to black coloured shale, sometimes calcareous and nodular; about $25 \mathrm{~m}$. thick; with many brachiopods, cephalopods, trilobites and other fossils.

Bed. $\mathrm{O}_{5}$. Makkol limestone. Composed of grey limestone, oolitic limestone, and black calcareous shale with fossils such as Orthoceras coreanicum Kobayashi and Asaphus sp.

Bed. $\mathrm{O}_{4}$. Dark blue or white limestone. A cranidium of Symphysurus sp. is probably derived from this horizon.

Bed. $\mathrm{O}_{3}$. Tomkol shale. Grey flinty calcareous shale with some limestone nodules and containing Asaphellus aff. hormfrayi (Salter), Hysterolenus sp., Cyrtometopus sp., Lingulella sp., and others.

Bed. O. Black calcareous slate, sometimes phyllitic.

Bed. Ol. Quartzite, $5 \mathrm{~m}$. thick.

Cambrian Formation.

Bed. $€_{8}$. Dark green, micaceous and phyllitic shale containing Eoorthis sp., Agnostus sp. and Cystoid gen. et sp. indet.

Bed. $\epsilon_{7}$. Grey limestone containing Chuangia batia (Walcott), Anomocare aff. subquadratum Dames and Billingsella aff. pumpellyi Walcott. 
Bed. $\epsilon_{1 \mathrm{i}}$. Seison slate. Grey slate with the typical Kushan fauna; collected at Seison-ni and Fachor-chih are:--

Lingulella sp., Agnostus cf. douvillei Bergeron, Stephanocare sp., Blackwelderia alastor (Walcott), B. sinensis (Bergeron), Damesella brevicauda Walcott, Drepaneura ketterelli Monke, D. premeshli Bergeron, Agraulos sp.

Bed. $\epsilon_{5}$. White crystalline limestone and oolitic limestone, with fragments of trilobites and Hyolites.

Bed. $\epsilon_{4}$. Banded limestone with intraformational limestone conglomerate; Agnostus chinensis Dames, Anomocare sp., and Anomocarella sp.

Bed. $€_{3}$. White crystalline limestone, bluish grey massive limestone and some oolitic limestone.

Bed. $\epsilon_{2}$. Red or green coloured shale and slate, sometimes micaceous; some white limestone lenses, with Anomocarella (?) sp. and some other fossils, in the lower part.

Bed. $\epsilon_{1}$. Black or blue calcareous slate.

Bed. $€$. White or blackish quartzite, partly conglomeratic.

$$
\text { unconformity }
$$

Underlying formation: Pre-Cambrian paragneiss of the Yokusen Series.

The Cambrian and Ordovician formations attain nearly $1800 \mathrm{~m}$. in total thickness. The Redlichia fauna of the Lower Cambrian being not yet found in South Korea, the lower limit of the Cambrian cannot be ascertained in this field; but the beds $\boldsymbol{e}^{-} \boldsymbol{\epsilon}_{6}$ are Middle Cambrian and older in age, because the bed $\epsilon_{6}$, Seison slate, is uppermost Middle Cambrian on the fossil evidence. Beds $\epsilon_{7}$ and $\epsilon_{8}$ are early and late Upper Cambrian respectively.

It can not be overlooked that the beds $\epsilon_{7}-\mathrm{O}_{4}$ altogether represent a regression phase of marine sedimentation, though the Bed $\mathrm{O}_{1}$ quartzite rests on the underlying late Upper Cambrian strata with an apparent conformity. From the palaeontological point of view, a faunal break of the first order of magnitude lies at the base of the quartzite. The faunas of the area now in consideration are rather similar to those of Tonking on one side and to those of North China and South Manchuria on the other, up to the close of the Cambrian Period. Since then, its faunas became quite distinct from those of the northern region. The Tomkol shale of South Korea is undoubtedly an equivalent of the Tremadoc shale of the British and Baltic Basins, whereas the Wanwanian of South Manchuria contains a fauna bearing a significant Ozarkian character of the Arcto-American region. This condition is best explained only by the assumption of the appearance of a certain barrier somewhere between the northern and southern Korea, which hindered the migration of marine organisms from north to south and vise versa. These are the very reasons why the quartzite is taken by me as the base of the Ordovician formation. 
Mr. Shiraki's collection of fossils obtained from a cliff of Seison-ni contains abundant remains of Pliomera seisonensis sp. nov. and Lichas sp.; the horizon may be called the Pliomera zone. This Pliomera zone as well as the Symphisurus limestone mentioned above presumably lie within the $\mathrm{Bed} \mathrm{O}_{5}$ which, I believe, stratigraphically corresponds to the Skiddavian.

Beds $\mathrm{O}_{5}, \mathrm{O}_{4}$ and $\mathrm{O}_{7}$ are very rich in fossils and their faunas are quite intimately related, so that they are better to be grouped together as the Chikunsan fauna, of which the important members are:

Diplograptus sp.

Orthis calligramma Dalman

Clionychia sp.

Modiolopsis aff. thebawi Reed

Palaeacmaea sp.

Sinuitopsis kochiriensis sp. nov.

Lophospira cf. pagoda Reed

Vaginoceras grabaui Kobayashi

Protocycloceras (?) deprati Reed

Primitia sp.
Basilicus shirakii sp. nov.

(Group of B. powisii Salter)

Asaphus yamanarii sp. nov.

(Group of $A$. expansus Wahl.)

Asaphus kawasakii sp. nov.

(Group of $A$. raniceps Dalm.)

Ogygites aff. yunnanensis Reed

Ogygites (?) yolusenensis sp. nov.

Ogygites (?) sp. nov.

Of these fossils, Diplograptus sp. resembles $D$. calcaratus var. vulgatus from the Dicranograptus shale of Britain; Basilicus powisii and Orthis calligramma are also the characteristic species from the lower part of the British Caradocian; the species of Asaphus, Ogygites and Vaginoceras have their related forms in the "Asaphusstufe" of the Baltic Basin. These principal components of the Chikusan fauna show a close affinity of it to the Llandeilo-Caradocian fauna of Europe, while some of other species have a slight resemblance to certain Black River-Trenton and Chazy species of North America. On the other hand, some of the Asaphids in the Chikunsan fauna are nearly identical with the pygidia of Asaphus described by Kayser and Weller from Sc'chuan and those by Frech and Yabe from Hupei and Kiangsi; hence a close relation between the Chikunsan fauna of South Korea and the Sükiapa-Neichiashan fauna of the Central China seems to be undeniable. Furthermore, it may be safely assured that a close affinity likewise exists between the Chikunsan fauna and the contemporaneous faunas of Yunnan and India, having Modiolopsis thebawi, Lophospira pagoda, Protocycloceras (?) deprati and Ogygites yunnanensis in common. The occurrence of Pliomera sp. in the lower horizon is also worthy of notice in this connection, because it is the genus very common in Burma and Yunnan.

We are now possible through the numerous contributions by Reed, Ellis, Gortani, Weber and Kiaer on Ordovician faunas to trace the Trilobite facies characteristic of the British and Baltic Ordovician 
through Khabasova, Kuznetsk Basin, Kirgis-Steppe, Pamir, Caracorum, Burma, South China and Central China to South Korea.

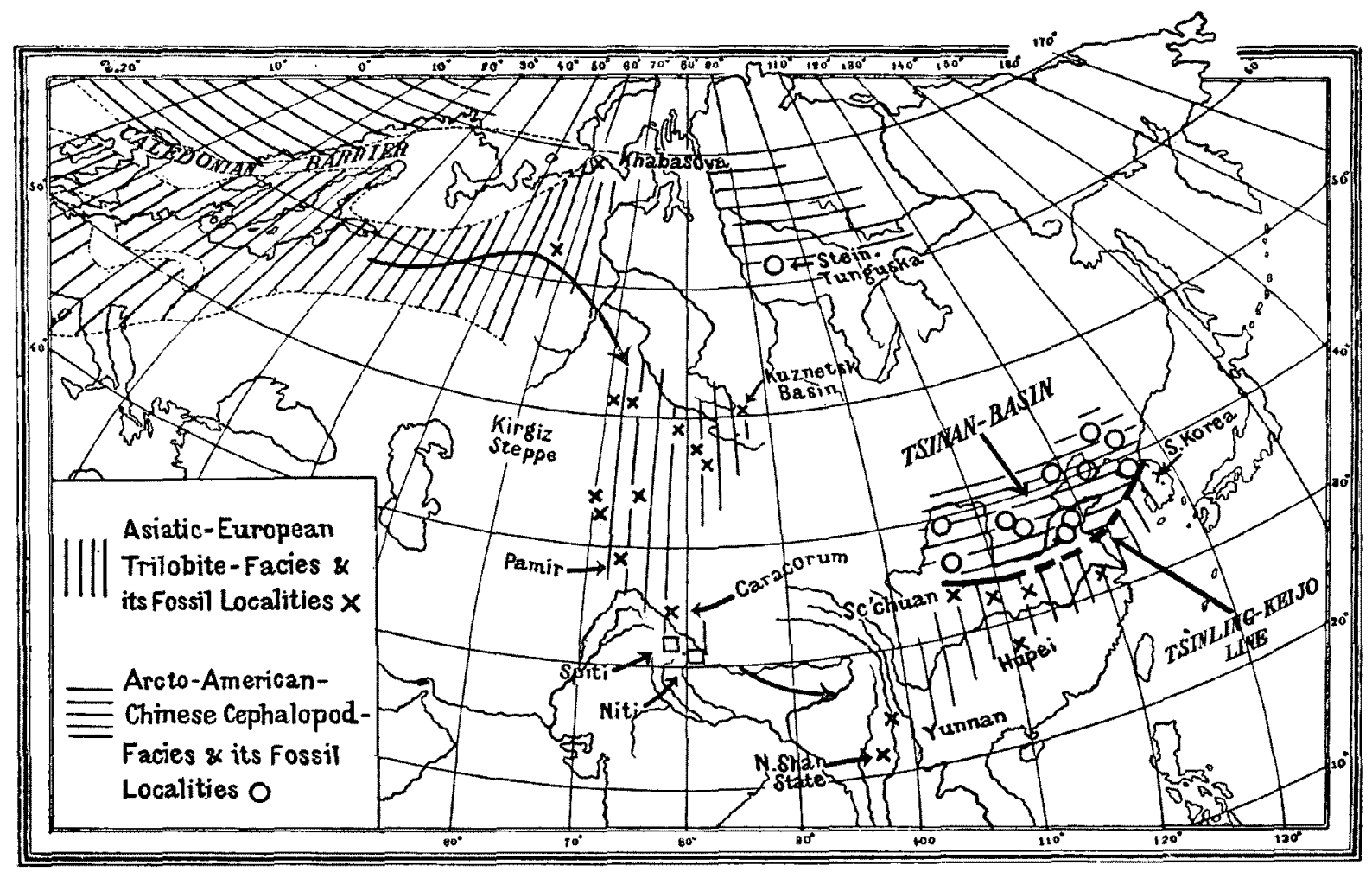

As to the Ordovician fauna of the Sükiapa Bed, Central China, Weller has already noticed that it has a striking affinity to the Vaginatenkalk of the Baltic Province, though certain resemblance to the fauna of the Black River-Trenton is also recognisable. The same is the case with South Korea. Such a separation of the southern fauna from the northern is in my opinion due to the existence of a certain barrier on the position extending from Tsinlingshan to Keijôthe Tsinling-Keijô Line, which is somewhat comparable in nature with the "Caledonische Schwelle"; it is very interesting that this line is subparallel to an important orogenic zone of a later date, just as the "Caledonische Schwelle" is with the Caledonian Mountains.

This Tsinling-Keijô Line marks the geographical boundary between the Southern and Northern Chinese Seas throughout the Ordovician Period, though it was possible for certain organisms, such as Orthis calligramma in the northern sea and Actinoceras sp. in the southern to go astray from one region into the other. 